DOI: $10.2478 / \mathrm{v} 10014-011-0012-\mathrm{x}$

Agrovoc descriptors: hordeum vulgare, barley, induced mutation, genes, genetic parameters, genetic variation, genomes, plant breeding, mutation, biodiversity, population dynamics, evolution, stress

Agris category code: F01, F30

\title{
Mutagenic treatment induces high transposon variation in barley (Hordeum vulgare L.)
}

\author{
Kornelia POLOK ${ }^{1}$ and Roman ZIELINSKI ${ }^{1}$
}

Received July 30, 2011; accepted September 14, 2011.

Delo je prispelo 30. julija 2011, sprejeto 14. septembra 2011.

\begin{abstract}
With more than 2700 mutant-derived cultivars, mutation techniques belong to the most efficient breeding methods. Despite a relatively good understanding of mutagenesis there is no agreement about the range of genome changes in mutants. Visualizing the gain and the loss of transposon insertion sites in SSAP profiles, the present studies aimed to answer whether or not mutants can be regarded as near isogenic lines with respect to their parent cultivar. Activities of BARE-1 retrotransposon and Tpo1-like DNA transposon from the CACTA superfamily were analysed in ten barley mutants derived by mutagenic treatment of two cultivars, Brenda and Scarlett. A large number and proportion of mutations (on average 21.4 mutations encompassing 19.7\% loci) confirm high efficiency of applied mutagens. However, differences exist among both cultivars and transposons. The lack of clear correlation between transposon activities and morphology reflects different mechanisms shaping the mutant architecture. With respect to a transposon type, BARE-1 and Tpo1-like were equally active in inducing mutations. However, their activity differs in that the former was mainly responsible for new insertions while the latter equally for insertions and deletions. An excess of new insertions over recombinational loss suggests a transposon burst as a response to stress caused by chemical mutagens. Low estimations of Nei's similarities, well within the range of semispecies demonstrate the role of mutagenic factors in diversification of populations. This way mutagenic treatment not only provides rough breeding materials but also can be used as a model in evolutionary studies.
\end{abstract}

Key words: Induced mutants, SSAP, BARE-1 retrotransposon, CACTA transposon, genetic similarity
IZVLEČEK

\section{MUTAGENO TRETIRANJE POVZROČA VISOKO VARIABILNOST TRANSPOZONOV PRI JEČMENU (Hordeum vulgare L.)}

Pri več kot 2700 kultivarjih gojenih rastlin so bili mutanti izhodišče za požlahtnitev, torej je induciranje mutacij ena od učinkovitih metod žlahtnjenja rastlin. Kljub razmeroma dobremu razumevanju procesa mutageneze ni soglasja o tem, kakšen je pri mutantih obseg sprememb genoma. S prikazom pridobitve ali izgube na mestih insercije transpozonov pri SSAP profilih poskuša ta raziskava pojasniti, če so mutanti skoro izogene linije $\mathrm{v}$ primerjavi $\mathrm{z}$ izhodiščnimi kultivarji. Aktivnost retrotranspozona BARE-1 in transpozonu Tpo1 podobnega iz superdružine CACTA je bila raziskana pri desetih mutantih ječmena, dobljenih z mutagenim tretiranjem dveh kultivarjev, Brenda in Scarlett. Veliko število mutacij in njihov delež (v povprečju 21,4 mutacij na 19,7\% lokusih) potrjuje učinkovitost uporabljenih mutagenov. Toda med obema kultivarjema in transpozoni so razlike. Ugotovljeno je, da ni jasne povezave med aktivnostjo transpozonov in morfologijo, kar se odraža v razlikah v mehanizmu formiranja oblik pri mutantih. Glede na vrsto transpozona sta BARE-1 in Tpo1-u sličen enako aktivna pri induciranju mutacij. Toda so razlike $\mathrm{v}$ aktivnosti glede na to, da prvo navedeni povzroča predvsem nove insercije, medtem ko drugi povzroča tako insercije kot delecije. Višek novih insercij $\mathrm{v}$ primerjavi $\mathrm{z}$ rekombinacijsko izgubo nakazuje, da je nastanek transpozonov povzročen s stresom, ki ga povzročijo kemični mutageni. Nizka ocena podobnosti po Nei-u, ki je v okviru podobne kot pri podvrstah, kaže na vlogo mutagenih dejavnikov pri diverzifikaciji populacij. Na ta način mutageno obravnavanje ne daje samo izhodiščnega materiala za žlahtnjenje rastlin, ampak je lahko uporabno tudi kot model v evolucijskih raziskavah.

Key words: inducirane mutacije, SSAP, BARE-1 retrotranspozon, CACTA transpozon, genetska podobnost

1 Department of Genetics, University of Warmia and Mazury in Olsztyn, Plac Lodzki 3, 10-967 Olsztyn, Poland, e-mail: kpolok@moskit.uwm.edu.pl 


\section{INTRODUCTION}

Mutation techniques employing chemical or physical agents belong to the most cost effective, simple and uncontroversial methods for changing plant traits. Today more than 2700 mutant-derived cultivars are registered in the FAO/IAEA Mutant Germplasm Repository (2006). Increased yields and enhanced quality of mutationderived cultivars have made a considerable impact on world food security and economy. Outstanding examples involve Zhefu 802 in rice, Jauhar 78 and Soghat 90 in wheat, NIAB-78 in cotton. It is also worth to mention barley cultivars, Diamant, Golden Promise and their 150 derivatives that have added billion of dollars to the value of the European brewing industry (Ahloowalia et al., 2004). In addition, induced mutations offer the unique features in gene discovery and functional genomic programmes. For instance, a key gene responsible for domestication of maize, teosinte branched1 (tb1) was identified in a recessive mutant of maize resembling the nearest close relatives, annual teosinte (Hubbard et al., 2002).

For research purposes, chemical mutagens such EMS (ethylmethane sulphonate), MNH (N-methyl-Nnitrosourea) and $\mathrm{NaN}_{3}$ (sodium azide) are the most widely used because they induce highly required mutations at single nucleotide pairs. Despite a relatively good understanding of this process there is no agreement about the range of genome changes in mutants. Mutations are induced with the frequency $10^{-5}-10^{-3}$ per locus, what implies that a mutant at a given locus can be found in a population of at least one thousand $\mathrm{M}_{1}$ plants. This probability is much lower when two or more mutations are searched. Hence, a commonly held view is that mutants and their parent cultivar are similar to near isogenic lines, differing in a limited number of mutated loci (Maluszynski et al., 2001). Even though initial variation is greater, selection is believed to fixate mutated alleles as exemplified by semi-dwarfism alleles such as sd1 in rice (Rutger, 2009) or Rht in wheat (Konzak, 1988). Additional yield changes of these mutants have often been explained as pleiotropic effects of mutated alleles. Recent studies showing that both the rice sd1 and wheat $R$ ht genes encode defective enzymes in the GAbiosynthetic pathway (Hedden, 2003) seem to provide strong evidence for this view.

A counterproposal frequently expressed is that during induced mutagenesis a lot of changes are generated in one nucleus and even though the selection is directed towards a certain trait, finally mutants differ by hundreds of mutated genes. Because these mutations are hardly visible in ordinary morphological screening, they have been described as background mutations. Great variation of quantitative traits commonly observed in induced mutants (Kulkarni et al., 1999; Barshile and Apparao, 2009; Sial et al., 2010) in addition to heterosis effects in crosses involving mutants from the same parent cultivar (or mutants and its parent cultivar) weight in favour of the high mutant diversity (Polok et al., 1997). Why then, can not these mutations be revealed by molecular techniques? In fact, microarray analyses have demonstrated that ionizing radiation may change expressions of more than 11 thousand genes (Batista et al., 2008). Unfortunately, there is a lack of systematic studies on the frequency of mutations induced by different mutagens at the DNA level. Presumably, breeding goals underlie behind a common drive for approaches detecting mutations in genes of particular economic interest.

Mutations are induced randomly in plant genomes, in which genes are only a tiny portion. In cereals, up to $80 \%$ of genomic DNA consists of repetitive DNA, mainly LTR retrotransposons (Devos, 2010). Being highly abundant and evenly distributed in plant genomes, transposons are good targets for studying mutation frequency in induced mutants. Furthermore, many mutants appear to result from transposon insertions such as albino rice plants (Fujino et al., 2005) or barley forms differing in susceptibility to powdery mildew (Wei et al., 2002). Mutations originated from transposon movements are easy to follow using Sequence Specific Amplification Polymorphism (SSAP). In the SSAP, products are derived from a DNA fragment between transposon sequences and restriction sites in the flanking sequences (Polok, 2007). When a transposon has integrated into a new site, it will appear as a polymorphic band present only in plants, in which the insertion has taken place. Barley (Hordeum vulgare L.), with a genome of ca. 5000 $\mathrm{Mb}$ comprising mainly transposon sequences (e.g., BARE-1, BAGY, MITE, Nikita Sukkula, Sabrina) is a suitable model for studying effects of mutagenic treatments. Among retrotransposons, BARE-1 elements occupy approximately $9.6 \%$ of the barley genome (Soleimani et al., 2006). There is no estimations of the DNA transposons' content in barley, nevertheless they can make up from $4.8 \%$ to $13.7 \%$ of cereal genomes (Devos, 2010).

In the present studies changes in a number of transposon insertion sites in barley mutants were estimated in order to answer whether mutants can be regarded as near isogenic lines with respect to their parent cultivar or perhaps they carry a lot of mutations and hence, they are highly diverged. Moreover, the behaviour of retrotransposons and DNA transposons in response to mutagenic treatment was compared. Diversity of induced mutants was also compared with inter- and intraspecific diversities of natural populations. 


\section{MATERIALS AND METHODS}

\subsection{Plant Material}

Ten mutants of Hordeum vulgare (L.) from the collection of the Department of Genetics, University of Warmia and Mazury were used in assessing transposon variation. These mutants were selected on the basis of their large morphological changes. Mutants were derived from two spring cultivars (parent cultivars), Brenda and Scarlett by double treatment of seeds with $\mathrm{MNH}$ and $\mathrm{NaN}_{3}$. All mutants represented stable, advanced generations, at least $\mathrm{M}_{8}$. Mutants from Brenda: 011B - stiff straw, dark leaves, shorter spikes, roots shorter and yield lower than in Brenda; 033B - semi-dwarf, stiff straw, spotted leaves (yellow and purple), short leaves, shorter roots and lower yield than in Brenda; 051B - taller than Brenda, purple leaf tips, short, thick leaves, yield higher than in Brenda; 052B - light green leaves, yield comparable with Brenda; 054B - brachytic type; 070B - semi-dwarf, shorter roots and lower yield than in Brenda. Mutants from Scarlett: 016S - dwarf, stiff and very short leaves, low yield; 026S - semi-dwarf, prostrate, twisted awns, short roots, very low yield, late; 029S - tigrina, low yield; 038S - dwarf, spots on leaves resembling disease symptoms, very low yield.

Plant genomic DNA was extracted from $1 \mathrm{~g}$ of 4-week old leaves using modified CTAB method (Polok, 2007). For each genotype 10 plants were used. The purity of DNA samples ranged between $89 \%-93 \%$ and the quantity between $61-237$ $\mu \mathrm{g}$.

\subsection{Transposon analysis by SSAP}

The SSAP methodology combines the general principle of AFLP with the sequence-specific PCR. This approach is similar to AFLP in that genomic DNA is digested with restriction enzymes, enzyme-specific adapters are ligated to the restriction products and the resultant fragments are preamplified. The final step, selective amplification uses a single adapter-specific primer together with a transposon-specific primer. The SSAP method as described by Polok (2007) was employed with the following modifications. Briefly, $360 \mathrm{ng}$ DNA was digested with MseI (3 U) and PstI (3 U) and ligated to enzyme specific adapters. Ligation mixtures were diluted 10 -fold to obtain final DNA concentration of $1 \mathrm{ng} / \mu \mathrm{l}$. Preamplifications were carried out in a $15 \mu \mathrm{l}$ final volume containing $20 \mathrm{mM}\left(\mathrm{NH}_{4}\right)_{2} \mathrm{SO}_{4}, 50 \mathrm{mM}$ Tris- $\mathrm{HCl}, \mathrm{pH} 9.0$ at $25^{\circ} \mathrm{C}, 2.0 \mathrm{mM} \mathrm{MgCl}_{2}, 1.5 \mu \mathrm{l}$ of Enhancer with betaine (Epicentre Technology), $200 \mu \mathrm{M}$ dNTPs, $0.5 \mu \mathrm{M}$ primers without selective nucleotides (Mse0, Pst0), $0.5 \mathrm{U}$ of $\mathrm{Tfl}$ polymerase (Epicentre Technology) and $5 \mu$ l of diluted ligation mixtures (equal to $5 \mathrm{ng}$ of DNA). Thermal conditions were: $94^{\circ} \mathrm{C}$ for $3 \mathrm{~min}$, followed by 30 cycles of $94^{\circ} \mathrm{C}$ for $60 \mathrm{~s}$, $60^{\circ} \mathrm{C}$ for $60 \mathrm{~s}, 72^{\circ} \mathrm{C}$ for $60 \mathrm{~s}$. The final extension was at $72^{\circ} \mathrm{C}$ for $7 \mathrm{~min}$. Pre-amplifications were diluted 5-fold and used for selective amplifications using an extended PstI primer (PstAT) in combinations with a transposon based primer. Selective amplifications were performed in a $10 \mu$ final volume containing $20 \mathrm{mM}\left(\mathrm{NH}_{4}\right)_{2} \mathrm{SO}_{4}, 50 \mathrm{mM}$ Tris- $\mathrm{HCl}, \mathrm{pH}$ 9.0 at $25^{\circ} \mathrm{C}, 1.5 \mathrm{mM} \mathrm{MgCl}_{2}, 1 \mu \mathrm{l}$ of Enhancer with betaine
(Epicentre Technology), $250 \mu \mathrm{M}$ dNTPs, $0.5 \mu \mathrm{M}$ Pst-AT primer, $0.5 \mu \mathrm{M}$ transposon specific primer, $0.5 \mathrm{U}$ of $\mathrm{Tfl}$ polymerase (Epicentre Technology) and $2.5 \mu \mathrm{l}$ of diluted preamplified DNA. Thermal conditions were: 12 cycles of $94^{\circ} \mathrm{C}$ for $30 \mathrm{~s}$, a touchdown phase starting at $65^{\circ} \mathrm{C}$ for $30 \mathrm{~s}$ with decrements of $0.7^{\circ} \mathrm{C}$ per cycle, and $72^{\circ} \mathrm{C}$ for $60 \mathrm{~s}$; then 28 cycles of $94^{\circ} \mathrm{C}$ for $30 \mathrm{~s}, 56^{\circ} \mathrm{C}$ for $30 \mathrm{~s}$ and $72^{\circ} \mathrm{C}$ for $60 \mathrm{~s}$. Products of selective amplifications were denatured with $8 \mu \mathrm{l}$ of $98 \%$ formamide at $94{ }^{\circ} \mathrm{C}$ for $7 \mathrm{~min}$, loaded on $6 \%$ denaturing polyacrylamide gels and separated at $45 \mathrm{~W}$ of constant power up to Bromophenol Blue run out of the gel. The gels were silver stained at $4^{\circ} \mathrm{C}$, dried, scanned using a flatbed scanner and pictures were stored as .jpg files.

Following primers were used in the SSAP:

SSAP standard primers. Mse adapters: MseF: 5'GACGATGAGTCCTGAG3', MseR: 5'TACTCAGGACTCAT3'; Pst adapters: PstF: 5'CTCGTAGACTGCGTACATGCA3', PstR: 5'TGTACGCAGTCTAC3'; pre-amplification primers: Mse0: 5'GATGAGTCCTGAGTAA3', Pst0: 5'GACTGCGTACATGCA G3'; primers with selective 3' bases: Pst-AT - 5'GACTGC GTACATGCAGAT3'.

Transposon based primers. BARE-1: 5'CTAGGGCATAATTCCAACAA3' - primer specific to the family of BARE-1 retrotransposons belonging to Ty1-copia like elements; Tpo1-like: 5'GATTGCCTTTTTCCTAGTAGTG-3' - primer produced from a terminal sequence of the $L$. perenne DNA transposon, Tpo1 belonging to the CACTA superfamily and highly abundant in grass genomes.

\subsection{Data analysis}

All bands that could be reliably read were scored either presence of a transposon insertion (1) or a deletion of a transposon site (0) and defined as follow. An insertional locus: a locus, in which a transposon insertion (band) was present in at least one genotype from a given combination (cultivar plus its mutants). Number of insertions: in a given genotype, total number of insertional loci, in which a transposon (band) was present. New insertion: a band was present in a mutant but no in its parent cultivar. Deletion: a band was present in a parent cultivar and lacking in its mutant. Total number of mutations was calculated by summarizing new insertions and deletions. The relative frequency of mutations was estimated as the percentage of mutations in relation to a total number of insertional loci observed in a given combination.

Factor ANOVA was used to check for cultivar, transposon type and interaction effects. The LSD test (Least Significant Differences) was used to examine differences between all possible pairs of means. All data were standardized and used in PCA (Principal Component Analysis). Genetic identities and distances were determined with the Nei and Li formula (Nei and Li, 1979). STATISTICA 9.0 software with own macros was used in calculations. 


\section{RESULTS}

\subsection{Insertional loci in Brenda and Scarlett genotypes revealed by SSAP}

Two transposons were used in SSAP reactions, namely BARE-1 belonging to the Ty1-copia-like retrotransposons and Tpo1, a member of the CACTA superfamily of DNA transposons. The first element is the best characterized retrotransposon in barley, thus it was not surprising that it produced high quality fingerprints. The Tpo1-like specific primer was designed on the L. perenne Tpo1 template (Polok, 2007). This primer produced a great number of bands in SSAP fingerprints confirming high abundance of Tpo1like transposons in barley. Both transposons were very effective in revealing insertional loci as confirmed by 110 loci observed in Brenda genotypes and 107 insertional loci in a case of Scarlett genotypes. Intracultivar variation was not observed what confirmed their uniformity. When cultivars were taken together with their mutants, high polymorphism was observed (Fig. 1). In total 41 insertional loci were polymorphic in
Brenda, which was $37 \%$. In Scarlett, respective values were 46 loci and $43 \%$.

\subsection{Mutation frequency in induced barley mutants}

Due to the uniformity of parent cultivars, a significant degree of polymorphism was assumed to result from mutation events. Two types of changes in SSAP profiles were observed in mutants i.e., new bands not present in a respective parent cultivar and the loss of bands (Fig. 1). The large average number of mutations (21.4), encompassing $19.7 \%$ indicated high efficiency of applied mutagens in inducing point mutations (Table 1). However, differences existed among both cultivars and transposons. Brenda seemed to be more resistant than Scarlett as emphasized by the smaller average number of SSAP changes (17.7 and 26.5, respectively) and the lower overall proportion of mutated loci $(16 \%$ and $24 \%$ ). This observation is in agreement with well known dependence of mutagen efficiency on genetic background.

Table 1. Transposon-derived mutations in barley mutants.

\begin{tabular}{|c|c|c|c|c|c|c|c|c|c|}
\hline & Total & & & BARE & & & Tpo1-1 & ike & \\
\hline \multirow[t]{2}{*}{ Mutant line } & \multirow{2}{*}{$\begin{array}{l}N^{\circ} \text { o } \\
\text { loci }\end{array}$} & \multicolumn{2}{|c|}{ Mutated loci } & \multirow{2}{*}{$\begin{array}{l}\mathrm{N}^{\circ} \text { of } \\
\text { loci }\end{array}$} & \multicolumn{2}{|c|}{ Mutated loci } & \multirow{2}{*}{$\begin{array}{l}\mathrm{N}^{\circ} \text { of } \\
\text { loci }\end{array}$} & \multicolumn{2}{|c|}{ Mutated loci } \\
\hline & & {$[\mathrm{n}]$} & {$[\%]$} & & {$[\mathrm{n}]$} & {$[\%]$} & & {$[\mathrm{n}]$} & {$[\%]$} \\
\hline \multicolumn{10}{|l|}{ Brenda } \\
\hline 011B & \multirow{6}{*}{110} & 15 & 13.6 & \multirow{6}{*}{60} & 3 & 4.9 & \multirow{6}{*}{50} & 12 & 24.0 \\
\hline 033B & & 12 & 10.9 & & 6 & 9.8 & & 6 & 12.0 \\
\hline 051B & & 16 & 14.5 & & 10 & 16.4 & & 6 & 12.0 \\
\hline 052B & & 16 & 14.5 & & 8 & 13.1 & & 8 & 16.0 \\
\hline 054B & & 20 & 18.2 & & 10 & 16.4 & & 10 & 20.0 \\
\hline 070B & & 27 & 24.5 & & 13 & 21.3 & & 14 & 28.0 \\
\hline $\begin{array}{l}\text { Mean }_{\text {Brenda }} \\
\pm \text { SD }\end{array}$ & & $\begin{array}{l}17.7 \mathrm{a} \\
\pm 1.8\end{array}$ & $\begin{array}{l}15.9 \mathrm{a} \\
\pm 1.6\end{array}$ & & $\begin{array}{l}8.3 \mathrm{a} \\
\pm 1.3\end{array}$ & $\begin{array}{l}13.7 \mathrm{a} \\
\pm 2.3\end{array}$ & & $\begin{array}{l}9.3 \\
\pm 1.3\end{array}$ & $\begin{array}{l}18.5 \\
\pm 2.3\end{array}$ \\
\hline \multicolumn{10}{|l|}{ Scarlett } \\
\hline $016 \mathrm{~S}$ & \multirow{4}{*}{107} & 29 & 27.1 & & 24 & 36.4 & & 5 & 12.2 \\
\hline $026 \mathrm{~S}$ & & 26 & 24.3 & $\mid$\begin{tabular}{||l}
66 \\
|
\end{tabular} & 18 & 27.3 & 41 & 8 & 19.5 \\
\hline 029S & & 28 & 26.2 & & 19 & 28.8 & & 9 & 21.9 \\
\hline $038 \mathrm{~S}$ & & 25 & 23.3 & & 16 & 24.2 & & 9 & 21.9 \\
\hline $\begin{array}{l}\text { Mean }_{\text {Scarlett }} \\
\pm \text { SD }\end{array}$ & & $\begin{array}{l}26.5 \mathrm{~b} \\
\pm 2.2\end{array}$ & $\begin{array}{l}24.4 \mathrm{~b} \\
\pm 1.9\end{array}$ & & $\begin{array}{l}\mathbf{1 9 . 3 b}[\mathrm{B}] \\
\pm 1.6\end{array}$ & $\begin{array}{l}\text { 29.1b [B] } \\
\pm 2.8\end{array}$ & & $\begin{array}{l}7.8[\mathrm{~A}] \\
\pm 1.6\end{array}$ & $\begin{array}{l}18.8[\mathrm{~A}] \\
\pm 2.8\end{array}$ \\
\hline $\begin{array}{l}\text { Mean }_{\text {All }} \\
\pm \text { SD }\end{array}$ & & $\begin{array}{l}21.4 \\
\pm 6.3\end{array}$ & $\begin{array}{l}19.7 \\
\pm 6.0\end{array}$ & & $\begin{array}{l}12.7 \\
\pm 6.5\end{array}$ & $\begin{array}{l}19.8 \\
\pm 9.5\end{array}$ & & $\begin{array}{l}8.7 \pm \\
2.8\end{array}$ & $\begin{array}{l}18.7 \\
\pm 5.4\end{array}$ \\
\hline
\end{tabular}

Different letters mean significant differences between means of Brenda and Scarlett mutants at $\mathrm{P}=0.05$. Different capitals in brackets mean significant differences between means of BARE-1 and Tpo1-like at $\mathrm{P}=0.05$, Mean $\mathrm{All}-$ an average of all ten mutants. 
A. BARE-1

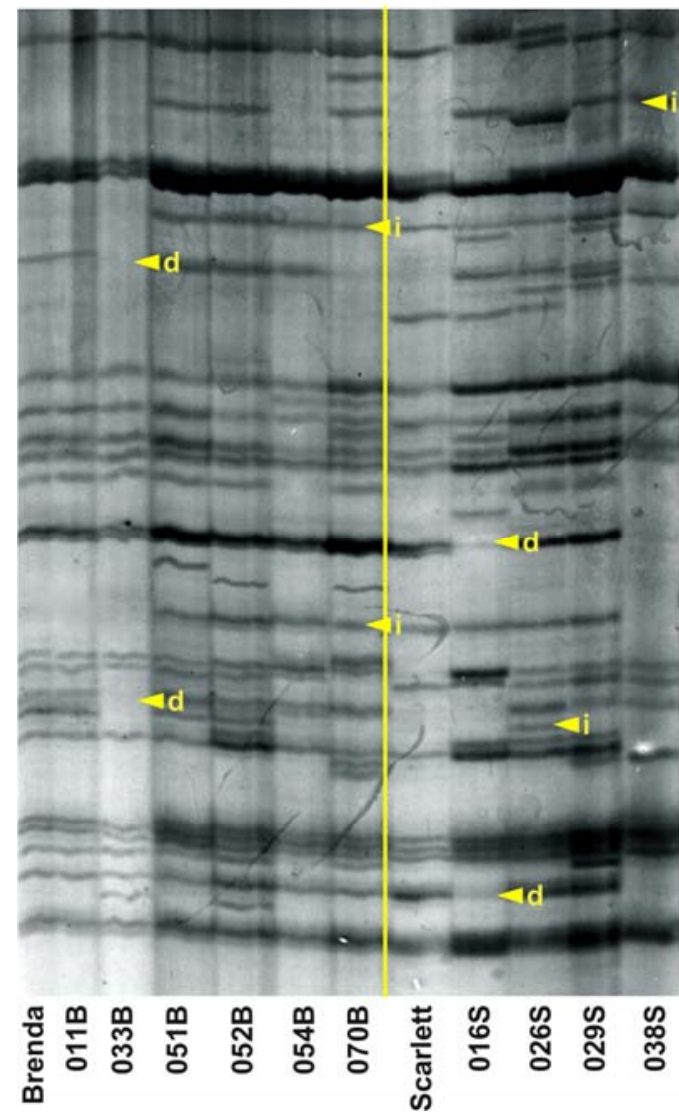

\section{B. Tpo-like}

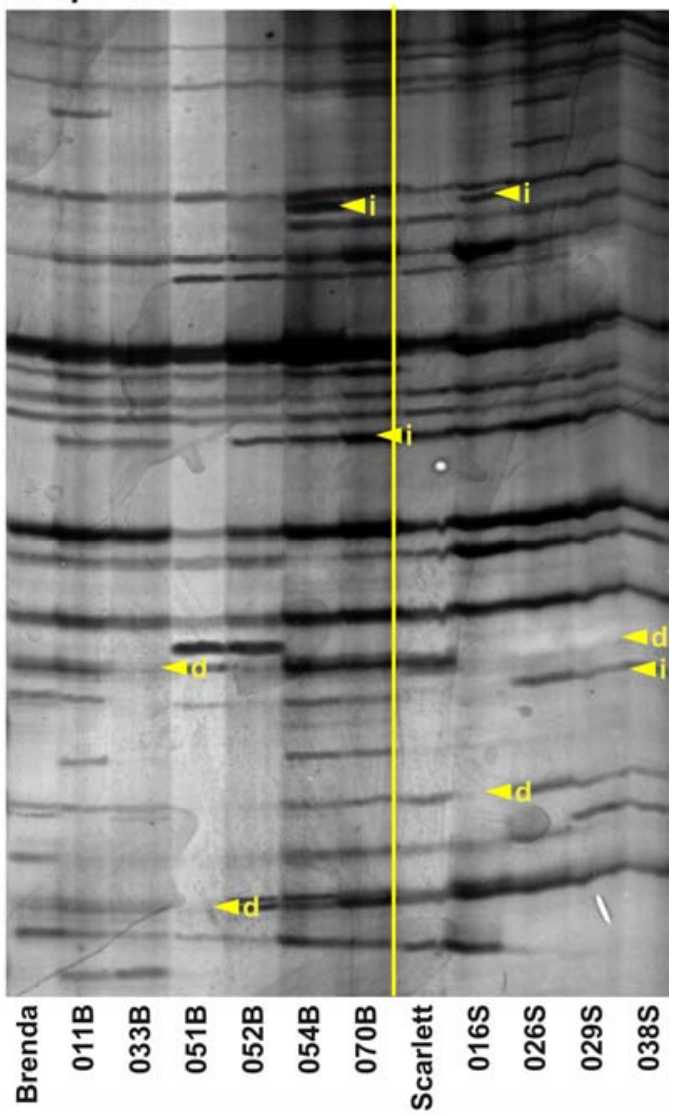

Fig. 1. SSAP fingerprints demonstrating insertion sites of BARE-1 (A) and Tpo1-like (B) transposons in barley mutants. Arrows indicate examples of new insertions (i) and deletions (d).

With respect to a transposon type, BARE-1 and Tpo1like were equally active in inducing mutations. Profiles of both transposons were characterized by similar number of mutated loci and their proportion (Table 1). However, BARE-1 fingerprints of Scarlett mutants were unusual in possessing the largest number and the largest proportion of recorded mutations (on average 19.3 mutations and 29.1\%). Noteworthy, in the Tpo1-like case, again genetic background proved to play a role. A general trend that Scarlett mutants carried more mutations than Brenda's was not obvious for Tpo1-like as demonstrated by 9.3 mutations in Brenda and 7.8 in Scarlett as well as respective proportions $18.5 \%$ and $18.8 \%$.

Mutants harboured from 12 to 29 mutations, which corresponded to $11 \%-27 \%$. Nevertheless, no clear correlations among mutation abundance and morphological changes were found. A largest number i.e., 25 and more mutations, and a similarly high percentage (above 23\%) were typical of all Scarlett mutants in addition to 070B (Fig. 2). This agreed well with numerous morphological changes in mutants with the exception of 070B differing from Brenda only in quantitative traits. Intermediate position was occupied by a brachytic type mutant, 054B with 20 mutations $(18 \%)$. This may indicate that most changes in leaf, spike, grain and root morphology accompanying by the brachytic mutation are partly due to pleiotropic effects. The lowest number (12 - 16) and proportion (11\% $15 \%$ ) of mutations were discovered in a group of four Brenda mutants, 011B, 033B, 051B and 052B. This was surprising because all of them expressed large degenerative traits including colour spots on leaves, light green leaves, aberrant leaf and root morphology and had been expected to carry many mutations. 
Kornelia POLOK, Roman ZIELINSKI

Table 2. Activity of BARE-1 and Tpo1-like transposons based on the gain and loss of SSAP insertion sites.

\begin{tabular}{|c|c|c|c|c|c|c|c|c|c|}
\hline \multirow{2}{*}{ Mutant line } & \multicolumn{3}{|l|}{ Total } & \multicolumn{3}{|l|}{ BARE-1 } & \multicolumn{3}{|l|}{ Tpo1-like } \\
\hline & $\begin{array}{l}\text { Insertion } \\
\mathrm{N}^{\mathrm{o}}\end{array}$ & $\begin{array}{l}\mathrm{New} \\
\text { Insertions }\end{array}$ & Deletions & $\begin{array}{l}\text { Insertion } \\
\mathrm{N}^{\mathrm{o}}\end{array}$ & $\begin{array}{l}\text { New } \\
\text { Insertions }\end{array}$ & Deletions & $\begin{array}{l}\text { Insertion } \\
\mathrm{N}^{\mathrm{o}}\end{array}$ & $\begin{array}{l}\text { New } \\
\text { Insertions }\end{array}$ & Deletions \\
\hline Brenda & 84 & & & 46 & & & 38 & & \\
\hline 011B & 87 & 9 & 6 & 49 & 3 & 0 & 38 & 6 & 6 \\
\hline 033B & 80 & 4 & 8 & 44 & 2 & 4 & 36 & 2 & 4 \\
\hline 051B & 92 & 12 & 4 & 54 & 9 & 1 & 38 & 3 & 3 \\
\hline 052B & 90 & 11 & 5 & 52 & 7 & 1 & 38 & 4 & 4 \\
\hline 054B & 93 & 12 & 8 & 50 & 7 & 3 & 43 & 5 & 5 \\
\hline 070B & 95 & 19 & 8 & 53 & 10 & 3 & 42 & 9 & 5 \\
\hline $\begin{array}{l}\text { Mean }_{\text {Brenda }} \\
\pm \text { SD }\end{array}$ & $\begin{array}{r}89.5 \\
+2.9 \\
\end{array}$ & $\begin{array}{l}11.2 \\
\pm 2.0 \\
\end{array}$ & $\begin{array}{l}6.5 \mathrm{a} \\
\pm 1.1 \\
\end{array}$ & \begin{tabular}{|l|l}
$\mathbf{5 0 . 3}[\mathrm{B}]$ \\
\pm 1.8 \\
\end{tabular} & $\begin{array}{l}6.3 \mathrm{a} \\
\pm 1.3 \\
\end{array}$ & $\begin{array}{l}\text { 2.0a [A] } \\
\pm 0.7\end{array}$ & \begin{tabular}{|l|}
$\mathbf{3 9 . 2}[\mathrm{A}]$ \\
\pm 1.8 \\
\end{tabular} & $\begin{array}{l}4.8 \\
\pm 1.3 \\
\end{array}$ & $\begin{array}{l}4.5[\mathrm{~B}] \\
\pm 0.7 \\
\end{array}$ \\
\hline Scarlett & 83 & & & 45 & & & 36 & & \\
\hline 016S & 94 & 20 & 9 & 57 & 18 & 6 & 37 & 2 & 3 \\
\hline $026 \mathrm{~S}$ & 91 & 17 & 9 & 55 & 14 & 4 & 36 & 3 & 5 \\
\hline 029S & 91 & 17 & 11 & 58 & 15 & 4 & 33 & 2 & 7 \\
\hline $038 \mathrm{~S}$ & 74 & 8 & 17 & 41 & 6 & 10 & 33 & 2 & 7 \\
\hline $\begin{array}{l}\text { Mean }_{\text {Scarlett }} \\
\pm \text { SD }\end{array}$ & $\begin{array}{r}87.5 \\
+3.5 \\
\end{array}$ & $\begin{array}{l}15.5 \\
\pm 2.5\end{array}$ & $\begin{array}{l}11.5 \mathrm{~b} \\
\pm 1.4\end{array}$ & \begin{tabular}{||l}
$52.8[\mathrm{~B}]$ \\
\pm 2.2
\end{tabular} & $\begin{array}{l}\text { 13.3b [B] } \\
\pm 1.6\end{array}$ & $\begin{array}{l}6.0 \mathrm{~b} \\
\pm 0.9\end{array}$ & $\begin{array}{l}34.8[\mathrm{~A}] \\
\pm 2.2\end{array}$ & $\begin{array}{l}2.3[\mathrm{~A}] \\
\pm 1.6\end{array}$ & $\begin{array}{l}5.5 \\
\pm 0.9\end{array}$ \\
\hline $\begin{array}{l}\text { Mean }_{\text {All }} \\
\pm \text { SD }\end{array}$ & $\begin{array}{l}88.7 \\
\pm 6.7 \\
\end{array}$ & $\begin{array}{l}12.9 \\
\pm 5.2 \\
\end{array}$ & $\begin{array}{l}8.5 \\
\pm 3.6\end{array}$ & \begin{tabular}{|l}
$\mathbf{5 1 . 3}[\mathrm{B}]$ \\
\pm 5.5
\end{tabular} & $\begin{array}{l}\mathbf{9 . 1}[\mathrm{B}] \\
\pm 5.2\end{array}$ & $\begin{array}{l}3.6 \\
\pm 2.9\end{array}$ & \begin{tabular}{|l}
$\mathbf{3 7 . 4}[\mathrm{A}]$ \\
\pm 3.3
\end{tabular} & $\begin{array}{l}3.8[\mathrm{~A}] \\
\pm 2.3\end{array}$ & $\begin{array}{l}4.9 \\
\pm 1.5\end{array}$ \\
\hline
\end{tabular}

Different letters mean significant differences between means of Brenda and Scarlett mutants at $\mathrm{P}=0.05$. Different capitals in brackets mean significant differences between means of BARE-1 and Tpo1-like at $\mathrm{P}=0.05, \mathrm{Mean}_{\mathrm{All}}-$ an average of all ten mutants.

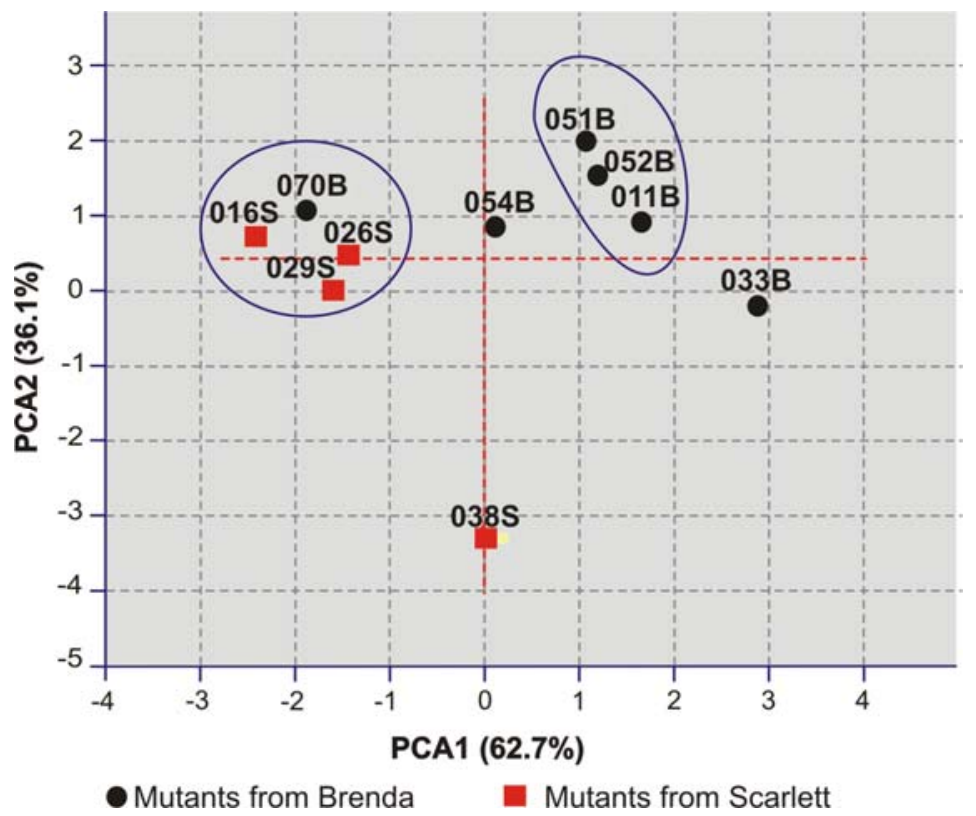

Fig. 2. Relationships of ten barley mutants revealed by the PCA analysis of SSAP data derived from BARE-1 and Tpo1-like transposons. 


\subsection{Assessment of BARE-1 and Tpo1-like activity after mutagenic treatment}

Visualizing the gain and the loss of fragments, SSAP fingerprints allowed to detect reorganisation in transposon fraction in response to mutagenic treatment. Almost identical number of insertion sites (84 and 83) in cultivars did not evidence any unusual transposon activities. Interestingly, a number of SSAP fragments increased in mutants (on average 89) indicating that new insertion sites appeared (Table 2). Likely, these new insertion sites were indicative of transposition. Comparable results were obtained for Brenda and Scarlett mutants with respect to insertion sites and new insertions. Inspecting new insertions, in particular BARE-1 seemed to rise more rapidly than Tpo1-like (9.1 and 3.8 new insertions, respectively). In Scarlett mutants, BARE-1 proliferated even five-fold faster than Tpo1-like. Among mutants, numerous transposition events were detected in three mutants, $016 \mathrm{~S}, 026 \mathrm{~S}$ and 029S (14-18 new insertions).

Further rearrangements in transposon sequences were indicated by SSAP fragment losses. On average, 8.5 deletions were observed but they were more frequent in Scarlett mutants with the maximum in 038S (17 deletions). Despite BARE-1 is a retrotransposon while Tpo1-like is a DNA transposon, their deletions were equally frequent (3.6 and 4.9). Relative ratios of new insertions and deletions inform about transposon contribution to an increase of genome sizes. An excess of BARE-1 new insertions over deletions ( $250 \%$ more) suggested BARE-1 specific genome rearrangements associated with mutagenic treatment. Recombinational loss is a major mechanism protecting genome from a retrotransposon burst. The more insertions in relation to the loss the more active are transposons. Thus, BARE-1 was highly active in eight mutants with the highest activity in $051 \mathrm{~B}$ and $052 \mathrm{~B}$ as demonstrated by seven to nine-fold more insertions. At this point, 033B and 038S mutants with inverted relationships (twice more BARE-1 deletions than insertions) were unusual. Their distinctiveness was also clear in the PCA plot (Fig. 2). Presumably, recombination processes acted against a transposon burst in these mutants. Expectedly, a balance between new insertions and deletions was generally noted for the DNA transposon, Tpo1-like (3.8 insertions vs. 4.9 deletions). Exceptions involved three Scarlett mutants with fewer insertions then deletions.

\subsection{SSAP diversity of induced barley mutants}

Estimates of Nei's genetic similarities between mutants and their parent cultivars were relatively low, well within the range of values normally associated with species at the early stages of divergence (Table 3 ). As expected, given the mutation numbers, Brenda mutants with the average Nei's index, 0.898 were more similar to their parent cultivar than Scarlett ones with the value of, 0.839. These estimates classified barley mutants as semispecies (Brenda's) or even subspecies (Scarlett's). Such an observation demonstrated the role of transposons activation through mutagenic treatment in population divergence.

Table 3. Nei's genetic similarities and distances between barley mutants and their parent cultivar assessed by BARE-1 and Tpo1-like transposons.

\begin{tabular}{|c|c|c|c|c|c|c|c|c|c|c|}
\hline & \multicolumn{6}{|c|}{ Brenda } & \multicolumn{4}{|c|}{ Scarlett } \\
\hline & 011B & 033B & 051B & 052B & 054B & 070B & $016 \mathrm{~S}$ & $026 \mathrm{~S}$ & 029S & $038 \mathrm{~S}$ \\
\hline Similarity & 0.912 & 0.923 & 0.909 & 0.908 & 0.884 & 0.849 & 0.836 & 0.851 & 0.828 & 0.841 \\
\hline Distance & 0.092 & 0.080 & 0.095 & 0.097 & 0.123 & 0.164 & 0.179 & 0.161 & 0.188 & 0.173 \\
\hline \multicolumn{11}{|c|}{ Common similarity values (Polok, 2007) } \\
\hline Populations & & $>0.925$ & & & & & & & & \\
\hline Semispecies & & $>0.873$ & & & & & & & & \\
\hline Subspecies & & $>0.759$ & & & & & & & & \\
\hline
\end{tabular}

\section{DISCUSSION}

It has been long suggested that mutagenic treatment can cause large diversity in plant genomes. Difficulties in mutant distinguishing on molecular levels and a huge number of mutant-derived cultivars differing only in a trait of interest, all these have seemed to confirm that mutants are alike near isogenic lines. This view has been dominant for years despite many obvious contrasting arguments including high variation of quantitative characters. The situation has only started to change recently when high-throughput molecular technologies targeted at different genomic elements became available. Mutation densities from one per 140 
$\mathrm{kb}$ in Arabidopsis to one per $400 \mathrm{~kb}$ in maize discovered by TILLING (Targeting Induced Local Lesions In Genomes) are only some of early examples questioning the near isogenic status of induced mutants. In the barley case, these values correspond to approximately 197 mutated genes per diploid genome (Till et al., 2004; Talame et al., 2008).

The overall picture from the present analyses is that mutagenic treatment induces huge genome changes likely driven by activation of transposons. Revealed SSAP fingerprints are characterized by more than a hundred of insertional loci of which about $40 \%$ are polymorphic among mutants and their parent cultivar. Mutants had up to $27 \%$ mutated loci what is much higher than it has been thought before. Given these numbers in gene equivalents, they are equal to nearly 10000 mutated genes assuming 53453 as the estimated gene number in barley (Sreenivasulu et al., 2008). This implies 50-fold more mutated genes in comparison with TILLING data (Talame et al., 2008) but it is consistent with the transcriptional changes in 11000 genes of irradiated rice mutants (Batista et al., 2008). Although demonstrative, this comparison may be somehow biased because the TILLING strategy is aimed at rapid identification of allelic series with point mutations at coding gene segments up to $1 \mathrm{~kb}-1.5 \mathrm{~kb}$ (Till et al., 2004). Conversely, SSAP profiles inform about the sites in whole genomes, in which transposons are inserted. It should be pointed however, that transposon insertions are coupled with point mutations at target sites.

New insertion sites in barley mutants suggest that BARE-1 and Tpo1-like transposons have played a role in inducing some morphological changes. Presumably, an insertion itself or resultant point mutations underlie behind at least some of morphological aberrations in barley mutants, for instance colour spots on leaves (033B, 038S). This hypothesis has strong roots in transposon insertions responsible for different expression of a1 alleles encoding purple anthocyanin pigments in maize (Pooma et al., 2002). In rice, the 607 bp transposable element that inserted into the gene encoding Mg-protoporphyrin IX methyltransferase, generated an $8 \mathrm{bp}$ target site duplication and finally an albino mutation (Fujino et al., 2005). Similar explanation may be valid for a tigrina mutant (029S) derived from Scarlett.

A potential difficulty arising from the "transposonorigin of morphological mutants" is the lack of clear connections between insertional polymorphism and morphological phenotypes. From one side, all Scarlett mutants characterized by large morphological changes carry highest numbers of mutations but this is not true for Brenda mutants. Surprisingly, the highest proportion of mutated loci was a feature of the $070 \mathrm{~B}$ mutant, which otherwise do not differ in major traits from Brenda. In this case, because differences are rather quantitative than qualitative, transposon insertions could take place in genes responsible for quantitative traits. This pattern explains well background mutations earlier postulated on the basis of significant differences in yield parameters in induced mutants as well as heterosis effects in crosses involving mutants originated from the same parent cultivar. Among postulated reasons dominant mutations increasing values of yield parameters and new interactions among non-allelic genes have been assumed (Polok et al., 1997; Polok, 1997). Hypothesis of transposon origin of mutations in genes controlling quantitative characters complements results from other plants. Eight from ten yield enhancing QTLs (Quantitative Trait Loci) from rice contain transposons from the CACTA superfamily and all classes of retrotransposons (Reddy et al., 2006). An intriguing association between QTLs and Tpo1 insertions as well as Ty1-copia like elements is observed on the Lolium perenne $\mathrm{x}$ L. multiflorum genetic map (Polok, 2007). Although a transposon role in shaping plant architecture needs further experimentations, the present studies demonstrate that new techniques may provide new insights into old phenomena.

Particularly intriguing is the presence of active transposons in barley mutants as deduced from high frequency of mutations (new insertions and deletions). Transpositional activity of mobile elements has persisted at a high level for million years in multiple cereal species (Leigh et al., 2003). This implies that transposons have a potential to move under certain conditions. For instance, drought stress in Evolution Canyon favours an increase in the BARE-1 copy number and a simultaneous decrease in the relative lost in Hordeum spontaneum (Kalendar et al., 2000). Similarly, retrotransposons are activated in wheat under Fusarium stress (Ansari et al., 2007). Then, why transposons could not be mobilised in response to mutagenic treatments. Postulated mechanisms may resemble these observed in yeasts, in which chemical mutagens activate a Ty1 retrotransposon in two ways, by direct DNA damaging effects and increased levels of reactive oxygen species (ROS). The last seems to play the major role in Ty1 mobilisation (Stoycheva, 2009). The activation of transposons from the CACTA superfamily in rice mutants (Batista et al., 2008) suggests that DNA transposons may also be activated by mutagenic treatments. However, this process may depend on background genotypes as deduced from different level of insertional mutations in barley cultivars. It can not be excluded that variation in sensitivity of different genotypes to mutagenic treatment is connected with different activities of transposons. However, this hypothesis needs more cultivars and mutants to study. 
The transposons, BARE-1 and Tpo1-like are distinct in their pattern of mobility after mutagenic treatment. This results from the transposon nature itself as well as from differences in their activity. Certainly, more insertion sites followed by more new insertions and mutated loci in a case of $B A R E-1$ are related to extremely high abundance of this retrotransposon in barley genome (Leigh et al., 2003). In contrast, DNA transposons, to which the Tpo1-like element belongs, are several times less frequent in plant genomes. A fact that there is only $27 \%$ less insertion sites than for BARE-1, the Tpo1-like transposon owes the membership to the CACTA superfamily, relatively abundant in cereals. An excess of new insertion sites over deletions in a case of BARE1 is attributed to the "copy and past" mechanism of retrotransposon movement while deletions can be explained by recombinational loss. By contrary, the DNA, Tpo1-like elements transpose through the "cut and past" mechanism, which is reflected by a balance among new insertions and deletions. Notwithstanding differences between BARE-1 and Tpo1-like elements, they seem to be equally active in response to mutagenic treatments as similar frequency of mutations suggests.
And last but not least, the present data demonstrate that mutant diversity is comparable with differences at the early stages of speciation. When applying commonly used similarity index, Brenda mutants could be classified as semispecies while Scarlett ones even as subspecies. This is not to say that we should treat them as new species. Induced mutants still belong to a species from which they are derived. This is rather a suggestion that induced mutants can provide a good model to study evolution, speciation and role of transposons in these processes. Frequency of spontaneous mutations in natural populations is believed to be higher at earlier stages of evolution. Similarly, many transposons, mobile in the past are stable at present. There are many uncertainties how the biological diversity has been created. Obviously, natural environment now and in the past has been a stressor to which plants would have had to adapt. This depends on genome adaptive abilities which are demonstrated by different responses of cultivars to chemical mutagens. Similarities of processes in the present and Evolution Canyon studies (Kalendar et al., 2000) rely on activation of transposons as adaptation to stress. This way mutagenic treatment can provide not only better crops but also mimic selective forces operating on a plant level.

\section{CONCLUSIONS}

1. High proportions of mutations in induced barley mutants deny their near-isogenic stage and confirm the view that a lot of mutations are induced during mutagenic treatment. Some of them can result from direct damages of DNA, however, the majority can be attributed to transposons' activation in response to stress.

2. Transposons can be distinct in their pattern of activity, but the majority of differences mirror differences between retrotransposons and DNA transposons.

3. The activity of transposons after mutagenic treatment can lead to substantial diversity of mutants, comparable to differences between species at early stages of divergence. This result confirms the role of transposons in speciation.

\section{ACKNOWLEDGEMENTS}

The research was supported in part by the European Union, the Marie Curie Host Fellowship for the
Transfer of Knowledge programme under the project GenCrop, MTKD-CT-2004-509834.

\section{REFERENCES}

Ahloowalia, B.S., Maluszynski, M., Nichterlein, K. 2004. Global impact of mutation-derived varieties. Euphytica 135: 187-204.

Ansari, K.I., Walter, S., Brennan, J.M., Lemmens, M., Kessans, S., McGahem, A., Egan, D., Doohan, F.M. 2007. Retrotransposon and gene activation in wheat in response to mycotoxigenic and non-mycotoxigenicassociated Fusarium stress. Theoretical and Applied Genetics 114: 927-937.
Barshile, J.D., Apparao, B.J. 2009. Genetic improvement of chickpea (Cicer arietinum L.) using induced mutations. In: Shu, Q.Y. (Ed.): Induced plant mutations in genomic era. Rome: Food and Agriculture Organization of the United Nations, pp. 91-94.

Batista, R., Saibo, N., Lourenco, T., Oliveira, M.M. 2008. Microarray analyses reveal that plant mutagenesis may induce more transcriptomic changes than transgene insertion. PNAS: 105: 3640-3645.

Acta agriculturae Slovenica, 97 - 3, september 2011 
Devos, K., M. 2010. Grass genome organisation and evolution. Current Opinion in Plant Biology 13: 139-145.

FAO/IAEA Mutant Germplasm Repository. 2006. [Database on the Internet]. [cited 2011 July]. Available from http://www-mgr.iaea.org

Fujino, K., Sekiguchi, H., Kiguchi, T. 2005. Identification of active transposon in intact rice plants. Molecular Genetics and Genomics 273: 150-157.

Hedden, P. 2003. The genes of the Green Revolution. Trends in Genetics 19: 5-9.

Hubbard, L., McSteen, P., Doebley, J., Hake, S. 2002. Expression patterns of mutant phenotype of teosinte branched1 correlate with growth suppression in maize and teosinte. Genetics 162: 1927-1935.

Kalendar, R., Tanskanen, J., Immonen, S., Nevo, E., Sculman, A.H. 2000. Genome evolution of wild barley (Hordeum spontaneum) by BARE-1 retrotransposon dynamics in response to sharp microclimatic divergence. PNAS 97: 6603-6607.

Konzak, C.F. 1988. Genetic analysis, genetic improvement and evaluation of induced semi-dwarf mutants in wheat. In: Semi-dwarf cereal mutants and their use in crossbreeding. Vienna: International Atomic Energy Agency, pp. 77-94.

Kulkarni, R.N., Baskaran, K., Chandrashekara, R.S., Kumar, S. 1999. Inheritance of morphological traits of periwinkle mutants with modified contents and yields of leaf and root alkaloids. Plant Breeding 118: 71-74.

Leigh, F., Kalendar, R., Lea, V., Lee, D., Donini, P., Schulman, A.H. 2003. Comparison of the utility of barley retrotransposon families for genetic analyses by molecular marker techniques. Molecular Genetics and Genomics 269: 464-474.

Maluszynski M., Szarejko, I., Barriga, P., Balcerzyk, A. 2001. Heterosis in crop mutant crosses and production of high yielding lines using doubled haploid systems. Euphytica 120: 387-398.

Nei, M., Li, W.H. 1979. Mathematical model for studying variation in terms of restriction endonucleases. PNAS 76: 5269-5273.

Polok, K. 1997. Application of doubled haploid lines in studies of heterosis in barley. Zesz Prob Post N Rol 451: 91-102. (In Polish, English abstract.).
Polok, K. 2007. Molecular evolution of the genus Lolium L. Olsztyn: "SQL", 317 p. Available at http://www.uwm.edu.pl/katgenbiol

Polok, K., Szarejko, I., Maluszynski, M. 1997. Barley mutant heterosis and fixation of $\mathrm{F}_{1}$-performance in doubled haploid lines. Plant Breeding: 133-140.

Pooma W., Gersos, C., Grotewold, E. 2002. Transposon insertions in the promoter of the Zea mays a1 gene differentially affect transcription by the Myb factors $\mathrm{P}$ and C1. Genetics 161: 793-801.

Reddy, C.S., Adari, P.B., Swamy, M.B.P., Neelamraju, S. 2006. Cytochrome $\mathrm{P} 450$ is a positional candidate gene for yield enhancing QTLs in rice [abstract]. In: $14^{\text {th }}$ plant and animal genomes conference. 2006 January 14-18; San Diego, CA, USA. Abstract $\mathrm{N}^{\circ} \mathrm{P} 266$.

Rutger, J.N. 2009. The induced sd1 mutant and other useful mutant genes in modern rice varieties. In: Shu, Q.Y. (Ed.): Induced plant mutations in genomic era. Rome: Food and Agriculture Organization of the United Nations, pp. 44-47.

Sial, M.A., Dahot, M.U., Laghari, K.A., Arain, M.A., Mangrio, S.M., Pirzada, A.J. 2010. Agronomic performance of semi-dwarf and dwarf wheat genotypes. World Applied Sciences Journal 8: 30-33.

Soleimani, V.D., Baum, V.D., Johnson, D.A. 2006. Quantification of the BARE-1 reveals the dynamic nature of the barley genome. Genome 49: 389-396.

Sreenivasulu, N., Graner, A., Wobus, U. 2008. Barley genomics: an overview. International Journal of Plant Genomics, doi:10.1155/2008/486258.

Stoycheva, T. 2009. Methylmethane sulfonate increases the level of superoxide anions in yeast cells. Biotechnology \& Biotechnol. EQ 23: 688-692.

Talame, V., Bovina, R., Sanguineti, M.C., Tuberosa, R., Lundqvist, U., Salvi, S. 2008. TILLMore, a resource for the discovery of chemically induced mutants. Plant Biotechnology Journal 6: 477-485.

Till, B.J., Reynolds, S.H., Weil, C., Springer, N., Burtner, C., Young, K., Bowers, E., Codomo, C.A., Enns, L.C., Odden, A.R., Greene, E.A., Comail, L., Henikoff, S. 2004. Discovery of induced point mutations in maize genes by TILLING. BMC Plant Biology 4:12, doi:10.1186/1471-2229-4-12.

Wei, F., Wing, RR.A., Wse, R.P. 2002. Genome dynamics and evolution of the Mla (Powdery Mildew) resistance locus in barley. The Plant Cell 14: 1903-1917. 